\title{
ECONOMIC POTENTIAL OF RURAL COMMUNES IN THE SWIETOKRZYSKIE PROVINCE IN RELATION TO DEVELOPMENT SPATIAL DIFFERENTIATION PATTERN
}

Pawel Dziekanski ${ }^{1}$, PhD; Adrian Lipa ${ }^{2}$, MSc.

${ }^{1}$ Institute of Law, Economics and Administration, Jan Kochanowski University in Kielce, Poland; ${ }^{2}$ Scientific and Educational Consortium

\begin{abstract}
It is natural for Poland's regions to differ in development. Differences result, among others, from attractiveness of location, deposits of raw materials, availability of human capital, and access to infrastructure and financial resources. Economic potential constitutes an important factor in the development process. The aim of the paper is to analyse spatial disparities in communal development against the background of economic potential. In the analysis, the TOPSIS method was used for the construction of the synthetic measure. The investigations were based on the data from Local Data Bank of Central Statistical Office for years 2012, 2014 and 2017, and also from Regional Accounting Chamber. They made it possible to create synthetic measures of economic potential and development of rural communes of the Swietokrzyskie province. Economic potential includes local labour market, level and type of entrepreneurship and infrastructure. The level and structure of economic potential are a condition of communal development. The communes of Sitkowka-Nowiny and Morawica, affected by the proximity of Kielce city, are the highest evaluated units. As their agricultural function is fading away, the industrial one is growing in importance.
\end{abstract}

Key words: economic potential, economic potential differentiation, development, commune, Swietokrzyskie province.

JEL code: L26, R1, P25, H72, R13.

\section{Introduction}

Communal local governments are most relevant for the economic development. That results from the economic and financial potential those bodies have, and also freedom in formulating development policy. The need to balance the economic, social and environmental goals in the long-term perspective calls for the local systems to be based on permanent development principles. Utilising endogenic factors (geographic environment resources, economy structure, condition of technical and social infrastructure etc.) in this process leads to increased overall welfare of the residents (Prus P., Drzazdzynska K., 2017).

The level of development of a given area reflects, among others, the quality of its competitiveness. The latter is affected by the economic potential of the entity, which includes the residents' labour market participation, the level of their income, labour market structure, level and type of entrepreneurship, and also the condition of the natural environment. The economic potential and entrepreneurship are related to the creation of new job opportunities, which positively contributes to the improvement of the living conditions of the local community.

The local development generated by communes is affected by many factors that are both dependent on and independent of the commune. They include economic, financial, infrastructural and demographic potentials. The analyses performed by Churski at al. (2013) and Stanny (2013) indicate that in addition to the socio-economic space, local finances also constitute an important contributing factor.

\section{Data and methods}

The paper aims to analyse spatial disparities in the development of communes with respect to the economic potential. In the analysis, the TOPSIS method was used for the construction of a synthetic

\footnotetext{
1 pdziekan@interia.eu

2 adrianlipa@konsorcjum.edu.pl
} 
measure. The analyses were conducted for 70 rural communes of the Swietokrzyskie province. The source material used for the study were data obtained from the Regional Accounting Chamber (Kielce branch) and Local Data Bank of Central Statistical Office for the years 2011, 2014 and 2017. For the assessment of the development of the rural communes in the Swietokrzyskie province, social, economic, infrastructural and financial variables were adopted as partial measures.

In order to determine the synthetic measure of development, the following procedure was applied (Dziekanski P., 2016, 2018).

1) The variables describing development, infrastructure, demography and financial condition of rural communes were identified and selected. The variables characterised by low spatial variation and high variable correlation, in accordance with the inverse matrix method (Malina A., 2004, 9667), were eliminated from the set. Economic potential, and communal development are determined by a number of factors that are economic, demographic and infrastructural in character.

2) Selected variables were subjected to the procedure of zeroed unitarization using the following formulas:

for the stimulant

$$
\begin{aligned}
& z_{i j}=\frac{\mathrm{x}_{i j}-\min _{i} x_{i j}}{\max _{i} x_{i j}-\min _{i} x_{i j}}, \text { when } x_{i} \in S(1), \\
& z_{i j}=\frac{\max _{i} x_{i j}-x_{i j}}{\max _{i} x_{i j}-\min _{i} x_{i j}}, \text { when } x_{i} \in D(2),
\end{aligned}
$$

for destimulants

where: S-stimulant, D-destimulant; $i=1,2 \ldots n ; j=1,2 \ldots n, x i j-$ denotes the value of the $j$-th feature for the unit of concern, max - maximum value of the $j$-th feature, min - minimum value of the $j$-th feature (Dziekanski p. 2016; Mioduchowska-Jaroszewicz E., 2013, 127-140; Wysocki F., 1996; Kukula K., 2000; Mlodak A., 2006).

3) The synthetic measures of development and economic potential were determined using the TOPSIS method. That involved the calculation of Euclidean distances from the positive-ideal solution and the negative-ideal solution for individual alternatives. Calculated measures were presented raging $(0,1)$, which allows the comparability of results. Values of the synthetic measures for individual objects were calculated on the basis of formula (3):

$$
q_{i}=\frac{d_{i}^{-}}{d_{i}^{-}+d_{i}^{+}}, g d z i e 0 \leq q_{i} \leq 1, i=1,2, \ldots, n ;(3),
$$

where: $d_{i}^{-}$- denotes the distance from the negative-ideal solution, $d_{i}^{+}$- distance from the positiveideal solution (Glowicka-Woloszyn R., Wysocki F., 2016; Wysocki F., 2010, 156-157). Indicator (3) takes on values from $[0,1]$ interval. A higher value of the indicator (close to unity) indicates more advantageous situation of the object, whereas a lower one (close to zero) denotes its weaker position (Zalewski W., 2012, 137-145).

4) The research area, namely the rural communes of the Swietokrzyskie province were divided into four quartile groups. The indicator magnitude in the first group is associated with a better unit, whereas in the last group it denotes the weakest unit. Based on the correlation coefficient, the congruence of the results obtained was verified. Additionally, the scatter graph with the line of fit was included (Dziekanski P., Wyszkowski A., 2018, 219-238; Wysocki F., Lira J., 2005).

\section{Research results and discussion}

The execution of statutory tasks by the commune and the policy it implements should contribute to local development. As indicated by Markowski $(2008,13)$, the latter is not defined in an unambiguous manner. The process of local development can be understood as e.g., a sum of qualitative transformations in the local structure that affect the living quality level of the community and the conditions of operation of the local businesses. Development is an economic process in 
character. It leads to the transformation of endogenic (local) factors of production into goods and services. The resultant quantitative and qualitative changes in a given area affect the living quality level of people and the conditions of operation of economy entities (Korenik S., 2011, 76).

The process of local development is shaped by the sum of endo- and exogenic factors. They include economic, social, technical, technological and ecological parameters. Those factors affect development processes and play a role in the removal of barriers to local development (Pajak K., 2011). The economic aspect of those activities involves enhancement of the welfare of the residents and improvement of their living conditions in the local territorial system (Brol R., 2008).

Economic conditions of the activities of the local government units are present both in the management of public monetary resources and the management of the commune assets. Improvement in economic potential and local entrepreneurship is translated into increased economic attractiveness. The latter can be defined as ability to provide investment incentives due to the offer of benefits, related to business location, possible to obtain while conducting a business activity. The local government working towards the provision of the optimal combination of the location factors can ensure the best conditions for the business operation (Kalinowski T., 2008).

The economic potential affects the economic development of the communes. At the same time, the economic potential stimulates economic changes resulting in increased production, employment, investments, amount of operating capital, income and consumption. Those parameters and related factors provide quantitative characteristics of the economy. They are also accompanied by qualitative changes. Therefore, economic potential can be viewed as multidimensional phenomenon determined by many factors that differ in character (Krakowiak-Bal A., 2006, 149-158).

In Poland, commune is the basic unit of the local government. It performs the tasks related to the development of its area. Commune has a number of tools at its disposal. The financial tools are of key importance as they decide the commune's autonomy and self-reliance (Truskolaski T., 2011). The commune's capability of attaining the assumed goals with respect to development depends on its economic condition. The latter can be evaluated using various indicators, the most important being the financial, economic potential or development indicators.

In the Swietokrzyskie province a clear-cut division into the region's industrial north and agricultural (including horticulture and arboriculture) southern and eastern parts is observed. The province's industries are closely related to natural resources available in the region for rock processing, production of chemicals and power generation. Metallurgy, machine industry and food processing are present as well. The province has clean natural environment and valuable landscape assets.

Synthetic measure of the development of rural communes in the Swietokrzyskie province indicates differentiation of the advancement of the units. The level is affected, among others, by the economic characteristics (industrial, agricultural) of unit, financial condition, and the economic potential. In 2012, development measure value ranged from 0.32 (Naglowice, the weakest unit, economic potential measure - group B) to 0.54 (Morawica, the strongest unit, economic potential group A). In 2017, the measure value varied from 0.37 (Naglowice, the weakest unit, economic potential measure - group B) to 0.63 (Sitkowka-Nowiny, the best unit, economic potential - group A). Shifts between the groups can be seen over time. Information on the unit belonging to a given group is important for an investor seeking a business location, and also may prove useful to both local and central authorities (Table 1). 
The location in the proximity of Kielce, the region's capital and its greatest centre performing an economic function, enhances the activities of rural areas aimed at developing new economic initiatives. Favourable position in the territorial space contributes to changes in the commune's structure and functions that become geared towards increased multifunctionality. The dominant units like Sitkowka-Nowiny, Morawica, Strawczyn are industrial and service-oriented, whereas their agricultural function is fading away.

Table 1

Classification of rural communes of the Swietokrzyskie province by the development synthetic measure in the years 2012, 2014 and 2017.

\begin{tabular}{|c|c|c|c|c|c|c|c|c|c|}
\hline & 2012 & 2014 & 2017 & 2012 & 2014 & 2017 & 2012 & 2014 & 2017 \\
\hline & & TOPSIS $_{R}$ & TOPSIS $_{\mathrm{G}}$ & & TOPSIS $_{R}$ & TOPSIS $_{\mathrm{G}}$ & & TOPSIS $_{R}$ & TOPSIS $_{\mathrm{G}}$ \\
\hline \multirow{4}{*}{$\mathbf{A}$} & Morawica & 0.54 & $A$ & Strawczyn & 0.56 & $A$ & $\begin{array}{c}\text { Sitkowka- } \\
\text { Nowiny }\end{array}$ & 0.63 & $A$ \\
\hline & $\begin{array}{c}\text { Sitkowka- } \\
\text { Nowiny }\end{array}$ & 0.53 & $A$ & Morawica & 0.55 & $A$ & Morawica & 0.58 & $A$ \\
\hline & Samborzec & 0.45 & $\mathrm{C}$ & Rakow & 0.47 & $B$ & Piekoszow & 0.49 & $B$ \\
\hline & $\begin{array}{l}\text { Skarzysko } \\
\text { Koscielne }\end{array}$ & 0.45 & $\mathrm{C}$ & $\begin{array}{c}\text { Ruda } \\
\text { Maleniecka }\end{array}$ & 0.47 & B & Wislica & 0.49 & C \\
\hline \multirow{4}{*}{ B } & Rytwiany & 0.44 & A & Blizyn & 0.46 & $D$ & Blizyn & 0.48 & $A$ \\
\hline & Sobkow & 0.44 & $\mathrm{C}$ & Bodzechow & 0.46 & $\mathrm{D}$ & Falkow & 0.48 & $\mathrm{D}$ \\
\hline & Tarlow & 0.43 & D & Sobkow & 0.45 & $\mathrm{C}$ & Wodzislaw & 0.46 & A \\
\hline & Wojciechowice & 0.43 & $\mathrm{C}$ & Tarlow & 0.45 & $\mathrm{D}$ & Zlota & 0.46 & A \\
\hline \multirow{4}{*}{ C } & Falkow & 0.42 & C & Gorno & 0.44 & C & Baltow & 0.45 & $A$ \\
\hline & Imielno & 0.42 & $\mathrm{C}$ & Obrazow & 0.44 & A & Laczna & 0.45 & $\mathrm{~B}$ \\
\hline & Sadowie & 0.39 & $B$ & Lagow & 0.42 & $B$ & Tuczepy & 0.44 & $A$ \\
\hline & Mniow & 0.39 & $\mathrm{D}$ & Wojciechowice & 0.42 & $\mathrm{C}$ & Wasniow & 0.44 & $\mathrm{D}$ \\
\hline \multirow{4}{*}{ D } & Blizyn & 0.38 & $\mathrm{D}$ & Baltow & 0.41 & A & Backowice & 0.43 & D \\
\hline & Lipnik & 0.38 & $\mathrm{D}$ & Czarnocin & 0.41 & $\mathrm{~B}$ & Klimontow & 0.43 & $\mathrm{D}$ \\
\hline & Naglowice & 0.34 & $B$ & Sadowie & 0.37 & $B$ & Moskorzew & 0.38 & $A$ \\
\hline & Bejsce & 0.32 & $\mathrm{C}$ & Naglowice & 0.33 & $\mathrm{~B}$ & Naglowice & 0.37 & B \\
\hline
\end{tabular}

TOPSIS $_{R}$ development synthetic measure; TOPSIS $_{G}$ economic potential synthetic measure

Table columns refer to quartile group / commune / value of development synthetic measure / value of economic potential synthetic measure; the Table lists two best and two weakest units of the group in a given year

Synthetic measure of the economic potential was constructed based on the following variables: entities entered in the register per 1,000 population (entrepreneurship index), natural persons conducting business activities per 1,000 population, foundations, associations and social organisations per 1,000 population (social involvement index), total registered unemployment, employees per 1000 population

Synthetic measure of development was constructed based on the following variables: synthetic measure of economic potential, synthetic measure of financial conditions, dwellings per 1,000 population, people number per one library, total internal migration balance, post-working age population per 100 working age population, rate of natural increase per 1,000 population, population with access to piped water supply in total population, population with access to sewer system in total population Source: author's calculations based on Local Data Bank of Central Statistical Office

The box-plot (Fig. 1) indicates a higher degree of scatter of units in 2012 (compared with 2014 and 2017) as the data are more dispersed and they take on more different values (cf. standard deviation, range, classic variation coefficient, Table 2). Regardless of the year, the outlier units included the communes of Morawica and Sitkowka-Nowiny, located in the proximity of the city of Kielce. Their agricultural function tends to disappear, whereas their industrial function is growing. 

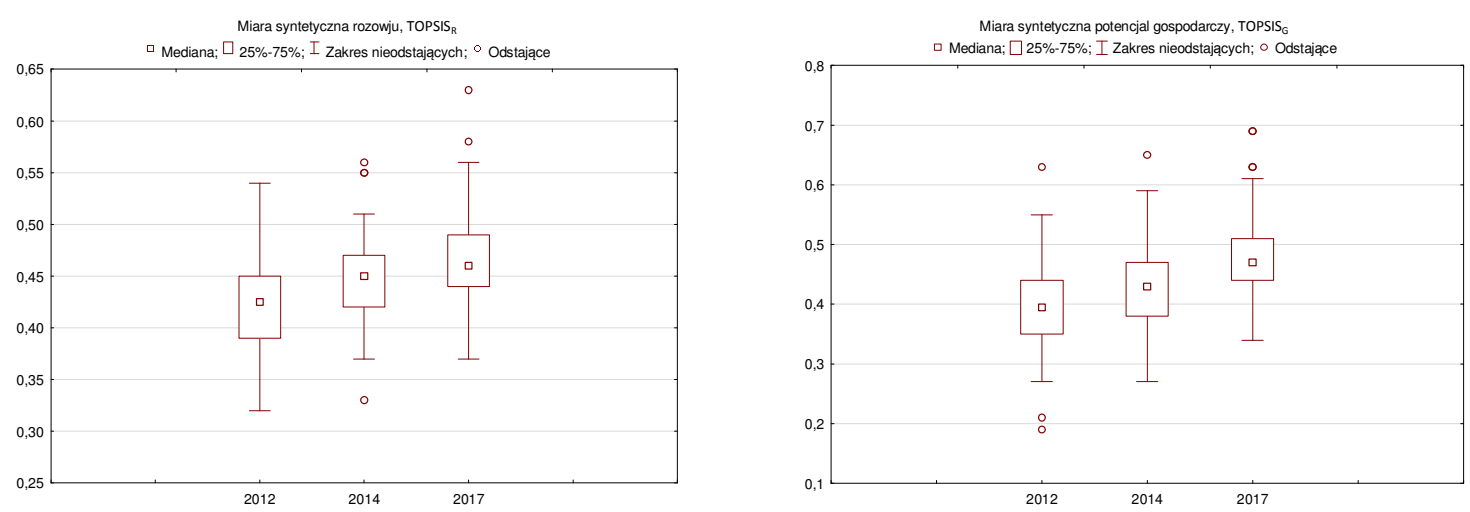

Source: author's calculations based on Local Data Bank of Central Statistical Office

Fig. 1. Plots of development and economic potential synthetic measures for rural communes of the Swietokrzyskie province in the years 2012, 2014, and 2017

The differentiation of the units in the Swietokrzyskie province rural communes in the analysed development area is stable, as shown by low values of standard deviation (development measure $0.04,0.04,0.04$, economic potential measure 0.08, 0.07, 0.047). For rural communes of the Swietokrzyskie province, the value of range shows relative stability (which is indicated by quartile range measure; development measure increased from 0.22 in 2012 to 0.26 in 2017, economic potential measure dropped from 0.44 in 2012 to 0.35 in 2017). A decrease in in the variation coefficient of economic potential indicates a greater statistical similarity of the units in the years 2012, 2014, 2017 (Table 2).

Table 2

Differentiation of development and economic potential synthetic measures in rural communes of the Swietokrzyskie province in the years 2012, 2014 and 2017

\begin{tabular}{|l|c|c|c|c|c|c|}
\hline & \multicolumn{3}{|c|}{ TOPSIS $_{\mathbf{R}}$} & \multicolumn{3}{c|}{ OOPSIS $_{\mathbf{G}}$} \\
\cline { 2 - 7 } & 2012 & 2014 & 2017 & 2012 & 2014 & 2017 \\
\hline $\begin{array}{l}\text { Standard } \\
\text { deviation }\end{array}$ & 0.04 & 0.04 & 0.04 & 0.08 & 0.07 & 0.07 \\
\hline Max & 0.54 & 0.56 & 0.63 & 0.63 & 0.65 & 0.69 \\
\hline Min & 0.32 & 0.33 & 0.37 & 0.19 & 0.27 & 0.34 \\
\hline Mean & 0.42 & 0.45 & 0.47 & 0.40 & 0.43 & 0.48 \\
\hline Range & 0.22 & 0.23 & 0.26 & 0.44 & 0.38 & 0.35 \\
\hline Quartile range & 0.06 & 0.05 & 0.05 & 0.09 & 0.09 & 0.07 \\
\hline $\begin{array}{l}\text { Variation } \\
\text { coefficient }\end{array}$ & 0.10 & 0.09 & 0.09 & 0.19 & 0.17 & 0.14 \\
\hline Asymmetry & 0.37 & 0.25 & 0.81 & 0.11 & 0.39 & 0.90 \\
\hline
\end{tabular}

TOPSIS $_{R}$ development synthetic measure; TOPSIS ${ }_{G}$ economic potential synthetic measure

Source: author's calculations based on Local Data Bank of Central Statistical Office

Table 3 lists coefficients of correlation between the values of synthetic measures of development and economic potential for rural communes of the Swietokrzyskie province. Coefficients of correlation demonstrate that in the years 2012, 2014, and 2017 spatial differentiation of development was stable. In the period of concern, Pearson coefficients of correlation between development synthetic measure and economic potential measure grew from 0.328 to 0515 in successive years. That might indicate a convergence process taking place in a given area, and increasing role of economic potential in the development of communes. 
Correlation of development and economic potential measures in rural communes of the Swietokrzyskie province in the years 2012, 2014 and 2017

\begin{tabular}{|l|c|c|c|c|}
\hline & \multicolumn{3}{|c|}{ Correlation coefficient } \\
\cline { 2 - 5 } & gamma & Spearman & Kendall tau & Pearson \\
\hline TOPSIS $_{\mathbf{R}} 2012-2014$ & 0.730 & 0.825 & 0.685 & 0.861 \\
\hline TOPSIS $_{\mathbf{R}} 2014-2017$ & 0.789 & 0.872 & 0.737 & 0.895 \\
\hline TOPSIS $_{\mathbf{R}}$ TOPSIS $_{\mathbf{G}} \mathbf{2 0 1 2}$ & 0.158 & 0.195 & 0.150 & 0.328 \\
\hline TOPSIS $_{\mathbf{R}}$ TOPSIS $_{\mathbf{g}} \mathbf{2 0 1 4}$ & 0.181 & 0.236 & 0.170 & 0.360 \\
\hline TOPSIS $_{\mathbf{R}}$ TOPSIS $_{\mathbf{G}} \mathbf{2 0 1 7}$ & 0.275 & 0.354 & 0.259 & 0.515 \\
\hline TOPSIS $_{\mathbf{G}}$ 2012-2014 & 0.885 & 0.946 & 0.854 & 0.965 \\
\hline TOPSIS $_{\mathbf{G}} \mathbf{2 0 1 4 - 2 0 1 7}$ & 0.821 & 0.903 & 0.784 & 0.936 \\
\hline
\end{tabular}

Correlations are significant for $p<0.050 ;$ TOPSIS $_{R}$ development synthetic measure rozwoj; TOPSIS $_{G}$ economic potential synthetic measure

Source: author's calculations based on Local Data Bank of Central Statistical Office

Figure 2 shows correlograms that describe relations between the synthetic measures of development and economic potential in the subsequent years of the period of concern. Development measure underwent convergence (Pearson correlation coefficient for the examined time interval and level increased from 0.860 to 0.895 , Fig. 2). Decrease in synthetic measure of economic potential from 0.964 to 0.936 points to a low divergence level. The positioning of the communes in the diagram in such a way they are aggregated may suggest they are statistically similar. The outlier units, namely are Morawica and Sitkowka-Nowiny, located near Kielce, have well-developed industrial function.
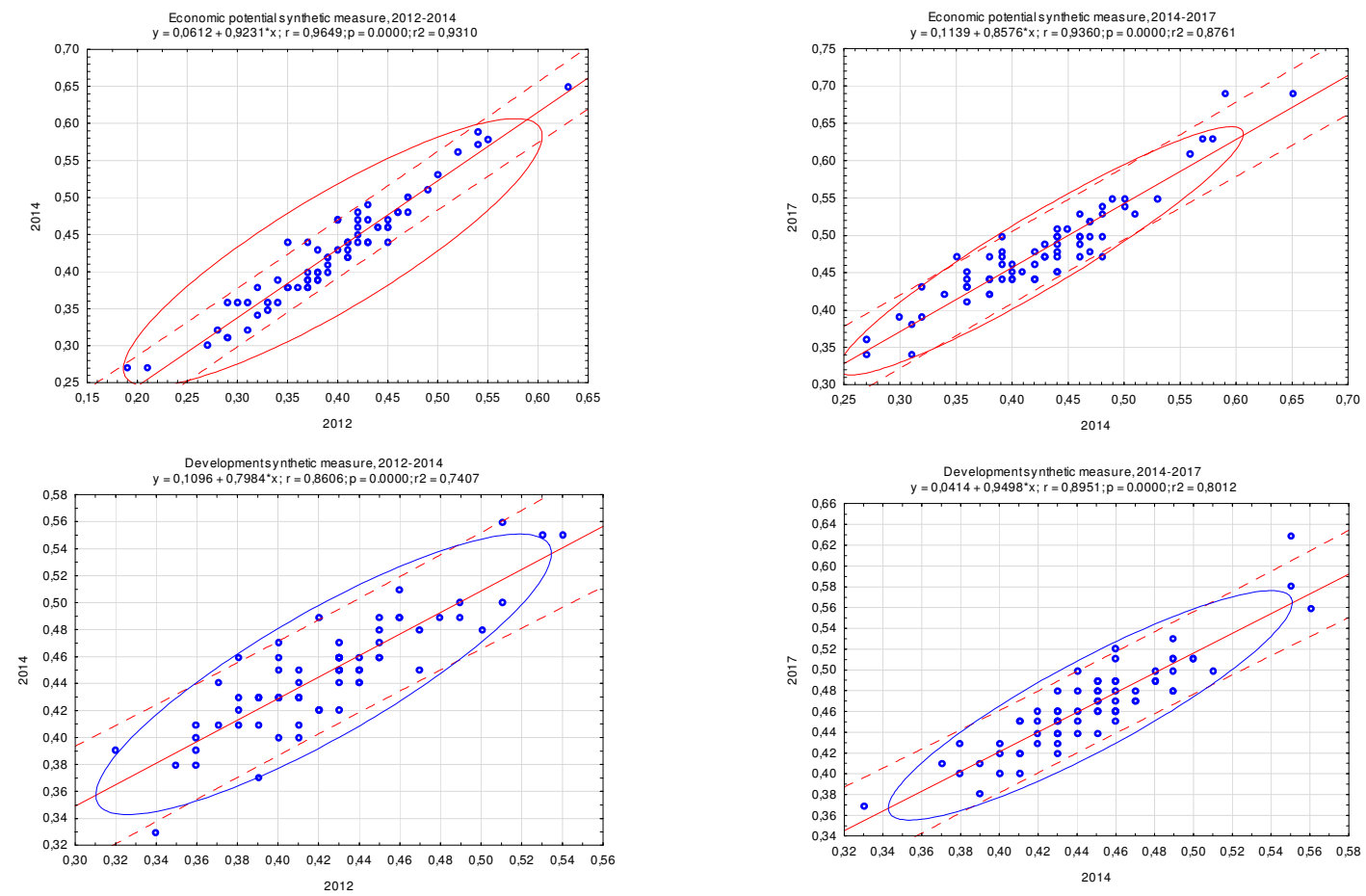

Source: author's calculations based on Local Data Bank of Central Statistical Office

Fig. 2. Relation of synthetic measures from year to year with fitted regression line

The analysis of the range diagram shows that increase in the coefficient values is accompanied by a change in the location of points which become positioned increasingly closer to the straight line. Figure 3 shows correlograms describing relations between the levels of development and economic potential measures. Compared with 2012, they underwent convergence in 2017 (Pearson correlation coefficients: $2012-0.328$ and $2017-0.515$; Fig. 3). Units with high value of economic level 
measure, i.e. Sitkowka-Nowiny and Morawica, at the same time, showed a high level of development measure.
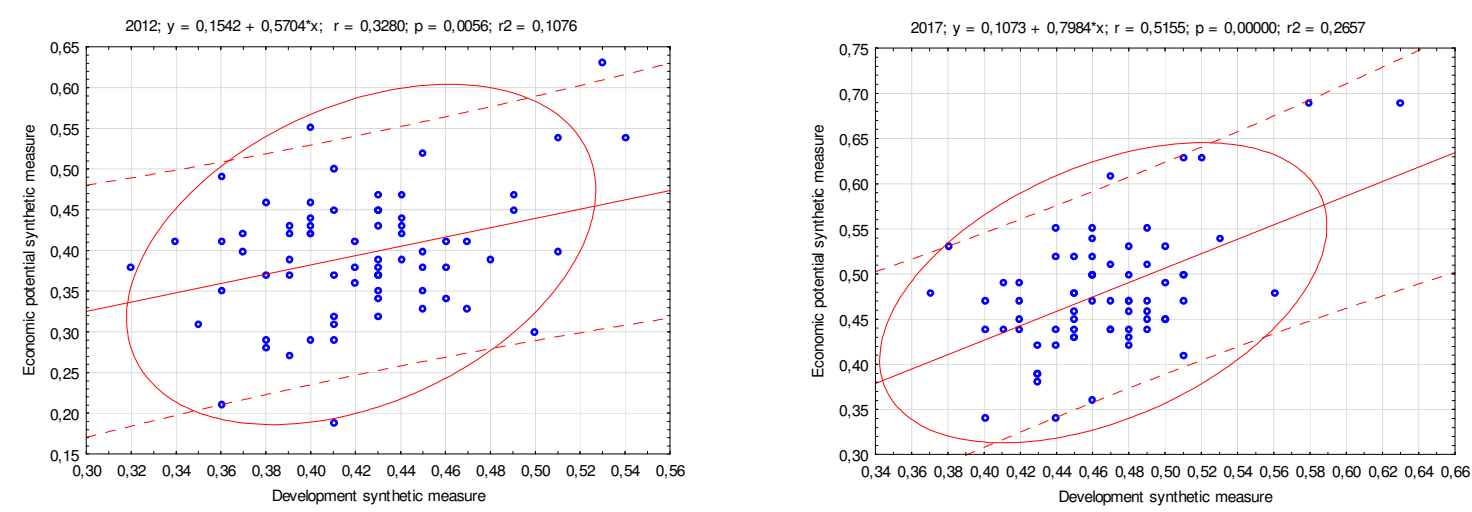

Source: author's calculations based on Local Data Bank of Central Statistical Office

Fig. 3. Relation of synthetic measures with the fitting of the regression line for rural communes of the Swietokrzyskie province (years 2012, 2014, and 2017)

\section{Conclusions, proposals, recommendations}

1) Decisions taken by the communal government bodies are directly and indirectly reflected in the local economy. The factors that allow planning activities related to current matters and investments are economic, infrastructural and demographic potentials. They also contribute to the development process of the communes.

2) The spatial polarisation processes, i.e. differences in development between the rich and poor areas tend to deepen. Rich areas develop due to the utilisation of their potential and favourable economic situation. Poor areas, however, are left behind for various reasons.

3) Economic potential of the communes consists of four components, namely economic, social, technical ecological potentials. They make it possible to create new structural combinations by rational utilisation of endogenic resources and the development process enhancement.

4) The operation of a unit or its development takes place in multidimensional space. The latter forms a network of relations and works towards the local community welfare. Effectiveness and efficiency of commune operation depends, to a large extent, on rational recognition and use of time and space variables.

5) The method used in the paper allows a comparative overview of the units analysed. The method makes it possible to identify stronger and weaker aspects of the unit activities. In the case of low spatial aggregations, data deficits are found that are most frequently caused by the lack of representativeness of data.

6) In 2012, the value of development synthetic measure ranged from 0.32 (Naglowice, the weakest unit, economic potential measure - group B) to 0.54 (Morawica, the strongest unit, economic potential - group A). In 2017, the measure value varied from 0.37 (Naglowice, the weakest unit, economic potential measure - group B) to 0.63 (Sitkowka-Nowiny, the best unit, economic potential - group A). The information on the unit belonging to a given group is valuable for investors, local, and also central authorities.

\section{Bibliography}

1. Brol, R. (2008). Kapital spoleczny w gospodarce lokalnej (Social capital in local economy). In: Gospodarka lokalna i regionalna w teorii i praktyce, (ed.) R. Brol. Prace Naukowe UE we Wroclawiu, nr 3.

2. Glowicka-Woloszyn, R., Wysocki, F. (2016). Kondycja finansowa gmin wiejskich a zrodla ich dochodow w wojewodztwie wielkopolskim (Financial condition of rural communes and sources of their income in the Wielkopolskie voivodship), Stowarzyszenie Ekonomistow Rolnictwa i Agrobiznesu Roczniki Naukowe, tom XVIII, zeszyt 1. 
3. Churski, P., Borowczak A., Dolata, M., Dominik, J., Hauke, J., Perdal, R., Konecka-Szydlowska, B. (2013). Czynniki rozwoju obszarow wzrostu i obszarow stagnacji gospodarczej w Polsce (Development factors in growth areas and economic stagnation areas in Poland), Uniwersytet im. Adama Mickiewicza, Poznan.

4. Dziekański, p. (2016). Spatial Changes and Assessment of the Financial Condition of Local Government Units in the Context of the Income Structure. In: Formankova S., International Conference on Management (ICoM), Trends of Management in the Contemporary Society (Peer-Reviewed Conference Proceedings), Brno, Publisher: Mendelova univerzita v Brně.

5. Dziekanski, p. (2016). Spatial Differentiation of the Financial Condition of the Świetokrzyskie Voivodship Counties. Barometr Regionalny, Tom 14 nr 3/2016, p. 79-91.

6. Dziekanski, p. (2018). Territorialisation of spatial disproportions of infrastructure and development of rural areas of the swietokrzyskie voivodship. In: Proceedings of the 2018 International Conference "Economic Science For Rural Development" No 47 Jelgava, LLU ESAF, 911 May 2018, p. 73-80.

7. Dziekanski, P., Wyszkowski, A. (2018). Ocena przestrzennego zroznicowania sytuacji finansowej gmin wojewodztwa swietokrzyskiego z wykorzystaniem miary syntetycznej (Asessment of spatial differentiation in the financial condition of the Swietokrzyskie province communes with the use of synthetic measure), Optimum. Economic Studies, nr 1 (91), p. 219-238.

8. Kalinowski, T. (ed) (2008). Atrakcyjnosc inwestycyjna regionow i podregionow Polski 2008 (Investment attractiveness of Poland's regions and subregions 2008). Instytut Badan nad Gospodarka Rynkowa, Gdansk.

9. Korenik, S. (2011). Region ekonomiczny w nowych realiach spoleczno-gospodarczych (Economic region under new social and economic conditions). CeDeWu, Warszawa, p. 76.

10. Krakowiak-Bal, A. (2006), Potencjal gospodarczy gmin przygranicznych Polski poludniowej (Economic potential of border communes in southern Poland). Infrastruktura I Ekologia Terenow Wiejskich. nr 2/2/, Polska Akademia Nauk. o/w Krakowie, p. 149-158

11. Kukula, K. (2000). Metoda unitaryzacji zerowanej (Zeroed unitarization method), PWN, Warszawa.

12. Malina, A. (2004). Wielowymiarowa analiza przestrzennego zroznicowania struktury gospodarki Polski wedlug wojewodztw (Multidimensional analysis of spatial differentiation of Poland's economy structure by provinces), Wyd. Akademii Ekonomicznej w Krakowie, Krakow, p. 96-97.

13. Markowski, T. (2008). Teoretyczne podstawy rozwoju lokalnego i regionalnego (Theoretical bases of local and regional development). In: Gospodarka regionalna i lokalna, (ed.) Z. Strzelecki. Wyd. Nauk. PWN, p. 13-28.

14. Mioduchowska-Jaroszewicz, E. (2013). Metody i kierunki oceny kondycji finansowej jednostek samorzadow terytorialnych (Methods and lines of assessment of the financial condition of local government units), ZN US, nr 786, Finansowe, Ubezpieczenia, nr 64/2, p. 127-140.

15. Mlodak, A. (2006). Analiza taksonomiczna w statystyce regionalnej (Taxonometric analysis in regional statistics), Difin, Warszawa.

16. Pajak, K. (2011). Rozwoj lokalny jako nowa kategoria ekonomiczna (Local development as a new economic category) In: Kryzys ekonomiczny a przestrzenny i funkcjonalny wymiar polityki gospodarczej, (ed.) K. Pajak, J.J. Tomidajewicz. Wyd. Adam Marszalek, Torun, p. 30-60.

17. Prus, P., Drzazdzynska, K. (2017). Farmers' Assessment of Training Services and the Impact of Agricultural Advisory on Selected Developmental Factors Affecting Farming. In: Proceedings of the International Scientific Conference "Economic Science for Rural Development", Latvia University of Agriculture, Jelgava, Latvia, No. 44, pp. 338-344.

18. Prus p. (2018). Farmers' Opinions about the Prospects of Family Farming Development in Poland. In: Proceedings of the 2018 International Conference "ECONOMIC SCIENCE FOR RURAL DEVELOPMENT", Jelgava, Latvia, No 47, pp. 267-274.

19. Stanny, M. (2013). Przestrzenne zroznicowanie rozwoju obszarow wiejskich w Polsce (Spatial differentiation in the develo pment of rural areas in Poland), IRWiR PAN, Warszawa.

20. Truskolaski, T. (2011). Strategiczne wyzwania rozwoju lokalnego na przykladzie Bialegostoku (Strategic challenges in the local development on the example of Bialystok). Samorzad Terytorialny, 12.

21. Wysocki, F. (1996). Metody statystycznej analizy wielowymiarowej w rozpoznawaniu typow struktury przestrzennej rolnictwa (Methods of multidimensional statistical analysis for recognizing types of agriculture spatial structure). Roczniki AR w Poznaniu, seria: Rozprawy Naukowe, z. 266, Poznan.

22. Wysocki, F. (2010). Metody taksonomiczne $w$ rozpoznawaniu typow ekonomicznych rolnictwa i obszarow wiejskich (Taxonomic methods for recognizing economic types of agriculture and rural areas), Wydawnictwo Uniwersytetu Przyrodniczego w Poznaniu. Poznan.

23. Wysocki, F., Lira, J. (2005). Statystyka opisowa (Descriptive Statistics). Wyd. Uniwersytetu Przyrodniczego w Poznaniu, Poznan.

24.Zalewski, W. (2012). Zastosowanie metody TOPSIS do oceny kondycji finansowej spolek dystrybucyjnych energii elektrycznej (TOPSIS method application to the assessment of the financial health of electricity distribution companies), Economics and Management, 4, p. 137-145. 